Original Research

\title{
Species Diversity of Carabid Beetles and Ants of Two Reclaimed Tailing Ponds
}

\author{
Mateusz Okrutniak*, Irena M. Grześ, Zbigniew Bonczar \\ Department of Environmental Zoology, Institute of Animal Science, University of Agriculture in Krakow, \\ Kraków, Poland
}

Received: 6 September 2017

Accepted: 28 November 2017

\begin{abstract}
Metal pollution can drastically decrease the diversity of species of many groups of terrestrial invertebrates. Well-performed reclamation may prevent the loss of species diversity. In this study, we used multivariable statistical methods to describe the species diversity of carabids and ants originating from two zinc-lead mine tailing ponds under different degrees of reclamation practices. Although the species diversity of carabids and ants in both study sites and in both seasons was relatively high, the investigated communities were dominated by one numerous species. Discriminant analysis indicated that the difference between study sites is due to the high number of carabid species found in the comprehensively reclaimed site and the high abundance of several species of ants found in the partially reclaimed site. The most striking difference in species composition between the study sites was the contribution of forest species. The comprehensively reclaimed site maintains more species of forest carabids but fewer forest species of ants in comparison to the partially reclaimed one.
\end{abstract}

Keywords: metal pollution, carabids, ants, community

\section{Introduction}

Southern Poland is rich in zinc and lead ore deposits, and a long tradition of mining activities in this region dating back to the 14th century has led to the accumulation of large amounts of different types of waste [1]. Despite the fact that the technology for mining ores has been much improved, waste still makes up more than $90 \%$ of the output, causing pollution and land degradation [2]. The by-products of contemporary ore extraction are post-flotation wastes deposited in tailing ponds that mainly contain different fractions of dolomite, organic compounds, and trace metals, mainly

*e-mail: m.okrutniak@urk.edu.pl zinc, lead, cadmium, and copper. Because a large part of this waste is represented by a fraction of small dust, the hillsides and the dried-out top area of the tailing ponds are exposed to eolian erosion that may lead to further trace metal contamination of neighbouring areas [3].

Well-performed reclamation may prevent this process. In general, the remediation technologies of metal-contaminated soils consist of two alternatives. Contaminants can be removed from the substratum by, e.g., electrokinetic remediation, soil washing, or phytoextraction [4-6]. Alternatively, pollutants can be immobilized by, e.g., chemical stabilization and phytostabilization [7-8]. Due to the costs, time, and logistical constrains in the case of post-flotation wastes, the first alternative is rarely applied. The most common technique is phytostabilization, which is relatively 
inexpensive and environmentally sustainable and gives a long-term and visually attractive effect. Nevertheless, metalliferous wastes are very unfavourable environments for plants, and their introduction must be performed followed by additional procedures. First, the surface of the wastes must be stabilized and shaped (technical phase) and then they must be covered by a humus layer, which constitutes a fertile substrate for plants (biological phase) [3].

Carabid beetles and ants are considered pioneers in reclaimed areas. As Carson and Root [9] proved, the herbivorous activities of carabids can be crucial for plant diversity and dominance during the early phases of succession. In turn, both carabid beetles and ants as predators control the communities of many invertebrates and can influence decomposition and nutrient-cycling processes [10-11]. Additionally, the activity of ants improves the physical and chemical properties of soil [12-14].

The aim of the present study was to describe species diversity of carabids and ants inhabiting two separate, reclaimed zinc-lead tailing ponds named Trzebionka and Bolesław. Both sites are extremely polluted by trace metals. Both tailing ponds are built of deposits of different ages. As a consequence, the plant cover represents variable stages of succession, from open areas to old forest stands. We endeavoured to collect samples of carabids and ants reflecting this heterogeneity; therefore, carabids and ants were sampled from various parts of the tailing ponds. Species diversity was described using multivariable statistical methods.

\section{Materials and Methods}

\section{Study Sites}

The present study was conducted at two tailing ponds: Trzebionka and Bolesław. The process of storing the waste in both tailing ponds was similar. The upper parts of the tailing ponds represent the youngest deposits of waste material, while the bases represent the oldest deposits. The study sites differ in the effects of the reclamation processes. The hillsides of Trzebionka have permanent plant cover representing different stages of succession, from early to advanced. Thus, the upper and lower parts of the pond are covered with planted herbaceous plants, shrubs, and trees, respectively. In turn, the hillsides of Bolesław tailing pond are at an early stage of succession and are dominated by herbaceous plants originating mainly from natural succession.

Trzebionka tailing pond is located in Trzebinia $\left(50^{\circ} 09^{\prime} \mathrm{N}, 19^{\circ} 25^{\prime} \mathrm{E}\right)$. It was established at the end of the 1960s and was in use until 2009. Trzebionka has a trapezoidal shape with a 64 ha base and a height of about $40 \mathrm{~m}$ [15]. The basic properties of the post-flotation wastes of Trzebionka are listed in Table 1. Both technical and biological reclamation work was simultaneously applied to restore the hillsides. The technical reclamation was based on reinforcing the hillsides with a layer of crushed dolomite. The biological phase consisted of covering the waste with a 30 -cm-deep humus layer, sowing grasses, and planting trees and shrubs that were selected for their high metal tolerance, drought tolerance, and low nutritional requirements. Additionally, the phytoremediation process was supported by a sprinkler system that watered the area during periods of drought [15].

The Bolesław tailing pond is located in Bolesław $\left(50^{\circ} 17^{\prime} \mathrm{N}, 19^{\circ} 29^{\prime} \mathrm{E}\right)$. It was established in the $1950 \mathrm{~s}$ and is still in use. The tailing pond has a trapezoidal shape and covers an area of 110 ha, rising above the surrounding terrain to a height of $42 \mathrm{~m}$ [17]. The basic properties of the post-flotation wastes of Bolesław are listed in Table 1. The technical reclamation conducted on Bolesław was based on reinforcing all hillsides with a layer of loamy deposit. The biological reclamation consisted of covering the waste with a 20 -cm-deep layer of humus with municipal sewage sludge and sowing grasses. Unlike Trzebionka, the plantings of trees and shrubs were not conducted simultaneously on all surfaces of the hillsides, but were introduced only to selected areas [18]. The small number of introduced plants and the lack of supporting the phytoremediation process by watering has led to the absence of permanent plant cover. In some small parts of the hillsides, planted species have disappeared and erosion has removed the soil over the waste, uncovering the substratum.

\section{Sampling}

The sampling of carabid beetles and ants was carried out on the hillsides of the tailing ponds from June to October in 2010 and 2011 (5 months in total). In both study sites, 60 pitfall traps filled with alcohol were installed. For each hillside exposition, i.e., north, south, and east, 20 pitfall traps were set up in two transects. One was placed on the upper part of the tailing ponds representing the youngest deposits (10 years), while the second transect was placed on the lower part representing the oldest deposits (40-50 years). The distance between the pitfall traps was $3 \mathrm{~m}$, while the distance between the transects was about $100 \mathrm{~m}$. The traps were exposed for the first three days of each month (June to October).

Table 1. Basic properties of post-flotation waste of the study areas, according to Trafas and Eckes [16].

\begin{tabular}{|c|c|c|c|}
\hline \multicolumn{2}{|c|}{} & Trzebionka & Bolesław \\
\hline $\mathrm{pH}$ & $\mathrm{H}_{2} \mathrm{O}$ & 8.5 & 7.85 \\
\cline { 2 - 4 } & $\mathrm{KCl}$ & 8.4 & 7.83 \\
\hline \multirow{2}{*}{$\begin{array}{c}\text { Contents of components } \\
\text { soluble in 60\% } \mathrm{HClO}_{4} \\
(\mathrm{mg} / \mathrm{kg})\end{array}$} & $\mathrm{Zn}$ & 13,453 & 11,358 \\
\cline { 2 - 4 } & $\mathrm{Pb}$ & 2,936 & 2,271 \\
\cline { 2 - 4 } & $\mathrm{Cd}$ & 91 & 64.4 \\
\hline
\end{tabular}


Table 2. Complete list of carabid beetles collected at the study sites.

\begin{tabular}{|c|c|c|c|c|}
\hline \multirow[b]{2}{*}{ Species } & \multicolumn{2}{|c|}{ Trzebionka } & \multicolumn{2}{|c|}{ Bolesław } \\
\hline & $\begin{array}{c}\text { Total } \\
\text { abundance }\end{array}$ & $\begin{array}{c}\text { Relative } \\
\text { abundance }\end{array}$ & $\begin{array}{c}\text { Total } \\
\text { abundance }\end{array}$ & $\begin{array}{l}\text { Relative } \\
\text { abundance }\end{array}$ \\
\hline 1. Leistus (Pogonophorus) rufomarginatus (Duftschmid, 1812). & 0 & 0.00 & 2 & 0.50 \\
\hline 2. Leistus (Leistus) ferrugineus (Linnaeus, 1758). & 2 & 0.28 & 3 & 0.75 \\
\hline 3. Notiophilus aquaticus (Linnaeus, 1758) & 2 & 0.28 & 0 & 0.00 \\
\hline 4. Cicindela (Cicindela) campestris campestris (Linnaeus, 1758) & 0 & 0.00 & 2 & 0.50 \\
\hline 5. Cicindela (Cicindela) hybrida hybrida (Linnaeus, 1758) & 0 & 0.00 & 3 & 0.75 \\
\hline 6. Loricera pilicornis pilicornis (Fabricius, 1775) & 1 & 0.14 & 0 & 0.00 \\
\hline 7. Carabus (Megodontus) violaceus violaceus (Linnaeus, 1758) & 7 & 0.97 & 0 & 0.00 \\
\hline 8. Epaphius secalis secalis (Paykull, 1790) & 1 & 0.14 & 0 & 0.00 \\
\hline 9. Asaphidion pallipes (Duftschmid, 1812) & 5 & 0.69 & 2 & 0.50 \\
\hline 10. Metallina (Metallina) lampros (Herbst, 1784) & 27 & 3.72 & 14 & 3.52 \\
\hline 11. Metallina (Metallina) properans (Stephens, 1828) & 7 & 0.97 & 7 & 1.76 \\
\hline 12. Metallina (Chlorodium) pygmaeum (Fabricius, 1792) & 2 & 0.28 & 14 & 3.52 \\
\hline 13. Bembidion quadrimaculatum (Linnaeus, 1761) & 0 & 0.00 & 1 & 0.25 \\
\hline 14. Anisodactylus (Anisodactylus) binotatus (Fabricius, 1787) & 0 & 0.00 & 3 & 0.75 \\
\hline 15. Anisodactylus (Pseudanisodactylus) signatus (Panzer, 1796) & 1 & 0.14 & 0 & 0.00 \\
\hline 16. Pseudoophonus (Pseudoophonus) rufipes (De Geer, 1774) & 39 & 5.38 & 4 & 1.01 \\
\hline 17. Harpalus (Harpalus) affinis (Schrank, 1781) & 1 & 0.14 & 0 & 0.00 \\
\hline 18. Harpalus (Harpalus) atratus (Latreille, 1804) & 2 & 0.28 & 3 & 0.75 \\
\hline 19. Harpalus (Harpalus) distinguendus distinguendus (Duftschmid, 1812) & 3 & 0.41 & 0 & 0.00 \\
\hline 20. Harpalus (Harpalus) luteicornis (Duftschmid, 1812) & 1 & 0.14 & 0 & 0.00 \\
\hline 21. Harpalus (Harpalus) quadripunctatus (Dejean, 1829) & 4 & 0.55 & 3 & 0.75 \\
\hline 22. Harpalus (Harpalus) rubripes (Duftschmid, 1812) & 32 & 4.41 & 4 & 1.01 \\
\hline 23. Harpalus (Harpalus) serripes serripes (Quensel in Schonherr, 1806) & 3 & 0.41 & 1 & 0.25 \\
\hline 24. Harpalus (Harpalus) smaragdinus (Duftschmid, 1812) & 13 & 1.79 & 0 & 0.00 \\
\hline 25. Harpalus (Harpalus) tardus (Panzer, 1796) & 2 & 0.28 & 0 & 0.00 \\
\hline 26. Bradycellus (Bradycellus) caucasicus (Chaudoir, 1846) & 0 & 0.00 & 1 & 0.25 \\
\hline 27. Poecilus (Poecilus) cupreus cupreus (Linnaeus, 1758) & 4 & 0.55 & 0 & 0.00 \\
\hline 28. Poecilus (Makropoecilus) sericeus (Fischer von Waldheim, 1824) & 1 & 0.14 & 7 & 1.76 \\
\hline 29. Pterostichus (Platysma) niger (Schaller, 1783) & 16 & 2.21 & 0 & 0.00 \\
\hline 30. Pterostichus (Pseudomasesus) nigrita (Paykul, 1790) & 1 & 0.14 & 0 & 0.00 \\
\hline 31. Calathus (Neocalathus) ambiguus (Paykull, 1790) & 415 & 57.24 & 236 & 59.30 \\
\hline 32. Calathus (Neocalathus) erratus (C, R, Sahlberg, 1827) & 53 & 7.31 & 63 & 15.83 \\
\hline 33. Calathus (Neocalathus) melanocephalus (Linnaeus, 1758) & 1 & 0.14 & 0 & 0.00 \\
\hline 34. Anchomenus (Anchomenus) dorsalis (Pontoppidan, 1763) & 0 & 0.00 & 1 & 0.25 \\
\hline 35. Amara (Amara) eurynota (Panzer, 1796) & 5 & 0.69 & 1 & 0.25 \\
\hline 36. Amara (Amara) littorea (C, G, Thomson, 1857) & 17 & 2.34 & 8 & 2.01 \\
\hline 37. Amara (Amara) spreta (Dejean, 1831) & 15 & 2.07 & 2 & 0.50 \\
\hline 38. Amara (Celia) bifrons (Gyllenhal, 1810) & 20 & 2.76 & 0 & 0.00 \\
\hline
\end{tabular}


Table 2. Continued.

\begin{tabular}{|c|c|c|c|c|}
\hline 39. Amara (Xenocelia) cursitans (C, Zimmermann, 1832) & 7 & 0.97 & 1 & 0.25 \\
\hline 40. Amara (Percosia) equestris equestris (Duftschmid, 1812) & 6 & 0.83 & 2 & 0.50 \\
\hline 41. Amara (Curtonotus) aulica (Panzer, 1796) & 1 & 0.14 & 0 & 0.00 \\
\hline 42. Badister (Badister) bullatus (Schrank, 1798) & 2 & 0.28 & 0 & 0.00 \\
\hline 43. Panagaeus (Panagaeus) cruxmajor (Linnaeus, 1758) & 2 & 0.28 & 0 & 0.00 \\
\hline 44. Cymindis (Cymindis) humeralis (Fourcroy, 1785) & 0 & 0.00 & 8 & 2.01 \\
\hline 45. Microlestes minutulus (Goeze, 1777) & 4 & 0.55 & 2 & 0.50 \\
\hline In total & 725 & 100 & 398 & 100 \\
\hline
\end{tabular}

The traps were emptied each month during both sampling periods (2010 and 2011). The pooled sample of 10 traps consisting of one transect was used as a replicate in further analysis. The identification of carabids and ant workers was performed according to Hůrka [19] and Czechowski et al. [20], respectively. The identification of both groups was performed based on morphological traits, namely antennae location, antennae pubescence, shape of pronotum and elytra, body size in carabids, and number of waist segments, femur, body color, head shape in ants.

\section{Statistical Analysis}

In order to describe the fauna of carabid beetles and ants in the study sites, discriminant analysis was performed. Study site (Trzebionka, Bolesław) was applied as a grouping variable, while species were used to design the discriminant functions. To simplify the discriminant function model, the forward selection method was applied. This means that variables (species) were added to the model one at a time. The final model contained only the significant variables of $\mathrm{F}$, having a value of over 4.0. Carabid beetles and ants as well as sampling period $(2010,2011)$ were analysed separately. Each replicate (case) applied to the analysis consisted of the community of carabid beetles or ants collected from each transect in each month in 2010 or 2011 . Thus 4 independent analyses

Table 3. Habitat preferences of carabid beetles and ants collected at the "Trzebionka" and "Bolesław" study sites. Each number denotes the percentage share of species representing a certain habitat preference. The categories were defined according to Hůrka [19], Czechowski et al. [20], and Aleksandrowicz [21].

\begin{tabular}{|c|c|c|c|c|}
\hline \multirow{2}{*}{ Category } & \multicolumn{2}{|c|}{ Carabid beetles } & \multicolumn{2}{c|}{ Ants } \\
\cline { 2 - 5 } & Trzebionka & Bolesław & Trzebionka & Bolesław \\
\hline Open areas & 46 & 67 & 42 & 33 \\
\hline $\begin{array}{c}\text { Forest or } \\
\text { open areas }\end{array}$ & 32 & 22 & 50 & 50 \\
\hline Forest & 14 & 7 & 8 & 17 \\
\hline Riparian & 8 & 4 & - & - \\
\hline
\end{tabular}

were performed: carabid beetles 2010, carabid beetles 2011, ants 2010, and ants 2011.

Additionally, in order to analyse the similarities in species composition between northern, southern, and eastern exposures we performed cluster analysis. To form the clusters, Ward's method with Euclidean distance metric was applied. The sampling period $(2010,2011)$ was analysed simultaneously in the case of carabid beetles as well as in the case of ants. All statistical analyses were performed with Statgraphics Centurion v. XVI (StatPoint Technologies, Inc., 2009).

\section{Results and Discussion}

\section{Species Diversity of Carabid Beetles}

In total, 1,123 specimens of carabid beetles belonging to 45 species were detected (Table 2) in Trzebionka and Bolesław, which is about $9 \%$ of all species of carabids found in Poland [21]. In general, all identified species (except for A. cursistans) are common and widespread throughout Poland [21]. Both study sites were dominated by $C$. ambiguus, whose relative abundance amounted to $57 \%$ and 59\% in Trzebionka and Bolesław, respectively (Table 2). C. ambiguus prefers dry and warm unshaded habitats [19], which can explain its high abundance. Schwerk and Szyszko [22-23] also identified the high abundance of Calathus carabids in post-industrial areas. In terms of habitat preferences, the community of carabid beetles of both sites was established mainly by species of open areas, though Trzebionka differed from Bolesław in terms of the higher number of forest carabids (Table 3). Most species identified in both study sites were of small or medium body size, which is in line with a similar study by Belskaya and Zolotarev [24] indicating that the contribution of small species of carabids is higher in disturbed than in undisturbed areas.

The discriminant analysis performed on carabid beetles collected in 2010 showed that 6 species $-A$. bifrons, A. euronota, A. cursistans, $P$. niger, B. bullatus, $P$. cruxmajor - can be used to design one function that significantly discriminates between Trzebionka and 
Table 4. Results of discriminant analysis performed on carabid beetles collected in 2010. The listed species were selected by the analysis to construct a significant function discriminating between the "Trzebionka" and "Bolesław" study sites. No discriminant function was designed from the data collected in 2011 due to the relatively low species F-values.

\begin{tabular}{|c|c|c|}
\hline Species & $\mathrm{F}$ & Standardized coefficient \\
\hline A. bifrons & 7.43 & 0.75 \\
\hline A. eurynota & 5.26 & 0.65 \\
\hline A. cursistans & 4.98 & 0.59 \\
\hline P. niger & 5.45 & 0.56 \\
\hline B. bullatus & 5.33 & 0.51 \\
\hline P. cruxmajor & 6.44 & 0.51 \\
\hline
\end{tabular}

Bolesław $(\mathrm{P}<0.01$, Table 4). In 2010 these species were detected in Trzebionka but not in Bolesław. Among these species, A. bifrons had the highest standardized coefficient (0.75, Table 4) being the most significant discriminator between Trzebionka and Bolesław. Although a similar analysis was performed using data collected in 2011, no discriminant function was designed because of the relatively low species-F values. Cluster analysis showed that northern, southern, or eastern exposures did not

a)

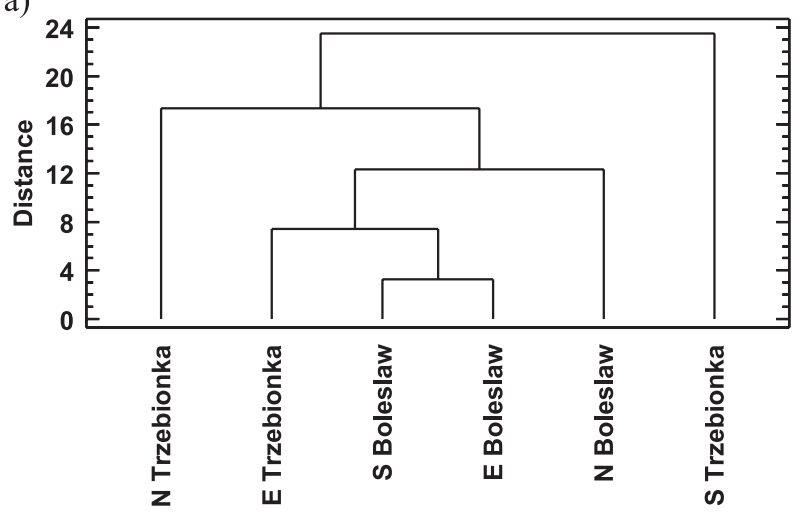

b)

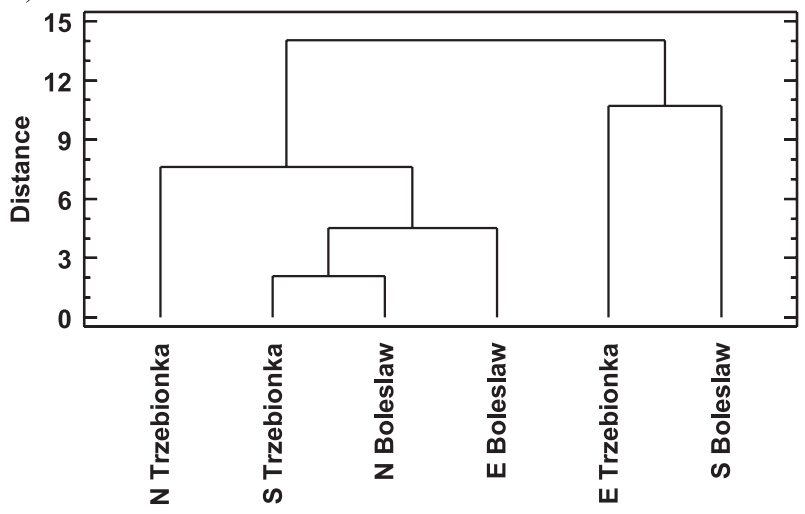

Fig. 1. The cluster analysis of the composition of species of carabid beetles a) and ants b) at the "Trzebionka" and "Bolesław" study sites. N, S, E- denotes the exposure. form distinct clusters (Fig. 1a), suggesting that exposure should not be considered a main factor shaping the variability of species diversity of carabids.

The higher number and abundance of carabids in Trzebionka than in Bolesław (Table 2) can be explained by the fact that more trees and other plants (such as Hippophae rhamnoides, Symphoricarpos albus, and Festuca ovina) were introduced for reclamation purposes in Trzebionka. This reclamation practice resulted in dense plant cover and hypothetically created more micro-climatically diverse habitats in Trzebionka than in Bolesław within a relatively small area. In Trzebionka, old forest stages of about 40-50 years are located at a distance of about $100 \mathrm{~m}$ from the areas covered by herbaceous plants (personal observation). According to Oliver et al., higher habitat heterogeneity provides more diverse resources and more differentiated niches that may meet the requirements of a much higher number of species than homogeneous habitats [25]. The heterogeneity-diversity relationship has been investigated in a number of studies, including beetles [26] and other insects [2728]. However, not all trends are positive [29-30], which is hypothesized to be influenced by the differences in resource availability between the investigated communities [31]. A positive correlation between plant cover and number of carabid species is widely recognized [32-34]. Dense plant cover can retain humidity [35], supporting the establishment of mesohygrophilous or hygrophilous carabids such as $C$. violaceus, A. signatus, and $P$. niger, found in the present study only in Trzebionka (Table 2).

\section{Species Diversity of Ants}

In total, 6,108 specimens of ants representing 16 species were identified (Table 5), which is about $16 \%$ of all species of ants found in Poland [20]. In general, all species identified in the study sites are common and widespread in Poland [20]. The ant community was dominated by one species, namely $F$. cinerea, whose relative abundance accounted for more than $80 \%$ and $40 \%$ in Trzebionka and Bolesław, respectively (Table 5). $F$. cinerea occupies thermophilic and xerophilic open habitats and forests, as well as sunny sandy sites with sparse vegetation [36].

As with the carabids, cluster analysis showed that exposure should not be considered a relevant factor that determines ant species diversity in investigated sites (Fig. 1b). In turn, the discriminant analysis applied to the ants collected in 2010 allowed us to construct one significant discriminating function based on two species: $M$. rubida and $F$. cinerea $(\mathrm{P}=0.01$, Table 6$)$. When data collected in 2011 were analysed, one significant discriminant function was constructed that included 3 species, i.e., M. ruginodis, L. niger, and M. rubida $(\mathrm{P}<0.01$, Table 6$)$. Based on an analysis of both seasons, M. rubida seems to be the most important discriminator between the study sites. In both seasons, this species was more abundant in Bolesław than in Trzebionka. M. rubida 
Table 5. Complete list of ants collected at the study sites.

\begin{tabular}{|c|c|c|c|c|c|}
\hline & \multirow[b]{2}{*}{ Species } & \multicolumn{2}{|c|}{ Trzebionka } & \multicolumn{2}{|c|}{ Bolesław } \\
\hline & & \multirow{2}{*}{$\begin{array}{c}\begin{array}{c}\text { Total } \\
\text { abundance }\end{array} \\
17\end{array}$} & \multirow{2}{*}{$\begin{array}{c}\begin{array}{c}\text { Relative } \\
\text { abundance }\end{array} \\
0.53\end{array}$} & \multirow{2}{*}{$\begin{array}{c}\begin{array}{c}\text { Total } \\
\text { abundance }\end{array} \\
0\end{array}$} & \multirow{2}{*}{$\begin{array}{c}\begin{array}{c}\text { Relative } \\
\text { abundance }\end{array} \\
0.00\end{array}$} \\
\hline 1. & Myrmica rubra (Linnaeus, 1758) & & & & \\
\hline 2. & Myrmica rugulosa (Nylander, 1849) & 14 & 0.44 & 17 & 0.59 \\
\hline 3. & Myrmica sabuleti (Meinert, 1861) & 1 & 0.03 & 0 & 0.00 \\
\hline 4. & Myrmica lonae (Finzi, 1926) & 2 & 0.06 & 0 & 0.00 \\
\hline 5. & Myrmica schencki (Emery, 1895) & 6 & 0.19 & 1 & 0.03 \\
\hline 6. & Manica rubida (Latreille, 1802) & 87 & 2.71 & 387 & 13.36 \\
\hline 7. & Stenamma debile (Förster, 1850) & 5 & 0.16 & 0 & 0.00 \\
\hline 8. & Tetramorium caespitum (Linnaeus, 1758) & 30 & 0.93 & 143 & 4.94 \\
\hline 9. & Formica (Formica) rufa (Linnaeus, 1761) & 0 & 0.00 & 170 & 5.87 \\
\hline 10. & Formica (Formica) truncorum (Fabricius, 1804) & 0 & 0.00 & 19 & 0.66 \\
\hline 11. & Formica (Serviformica) fusca (Linnaeus, 1758) & 10 & 0.31 & 1 & 0.03 \\
\hline 12. & Formica (Serviformica) cinerea (Mayr, 1853) & 2,670 & 83.15 & 1,366 & 47.15 \\
\hline 13. & Formica (Serviformica) cunicularia (Latreille, 1798) & 19 & 0.59 & 2 & 0.07 \\
\hline 14. & Formica (Raptiformica) sanguinea (Latreille, 1798) & 0 & 0.00 & 40 & 1.38 \\
\hline 15. & Lasius (Lasius) niger (Linnaeus, 1758) & 350 & 10.90 & 750 & 25.89 \\
\hline 16. & Lasius (Chthonolasius) distinguendus (Emery, 1916) & 0 & 0.00 & 1 & 0.03 \\
\hline & In total & 3,211 & 100 & 2,897 & 100 \\
\hline
\end{tabular}

is montane species frequent in Central and south-eastern Europe occurring at 500-2,000 m a.s.l. [36]. Even though this species is considered typical for mountain grassy habitats, it was also recorded in the lowlands and also on coal mining spoil dumps [37]. It was concluded that $M$. rubida is an efficient colonizer of disturbed areas [37].

In terms of habitat preferences, the community of ants of both sites was established mainly by forest and open-area-species (e.g. M. schencki, F. cinerea, L. niger),

Table 6. The results of the discriminant analysis performed on ants collected in 2010 and 2011. The listed species were selected by the analysis to construct a significant function discriminating between the "Trzebionka" and "Bolesław" study sites.

\begin{tabular}{|c|c|c|}
\hline Species & $\mathrm{F}$ & Standardized coefficient \\
\hline \multicolumn{3}{|c|}{2010} \\
\hline M. rubida & 4.59 & 0.74 \\
\hline F. cinerea & 4.01 & -0.70 \\
\hline \multicolumn{3}{|c|}{2011} \\
\hline M. ruginodis & 5.85 & 0.85 \\
\hline L. niger & 4.50 & -0.60 \\
\hline M. rubida & 4.88 & -0.88 \\
\hline
\end{tabular}

but more forest species, such as F. rufa, F. truncorum, were found in Bolesław than in Trzebionka (Table 3). The forest species detected in Bolesław may be foragers from the coniferous forest located close to the study area, as species such as F. rufa can forage over distances greater than $100 \mathrm{~m}[20]$.

\section{Conclusions}

To summarize, although the investigated sites are relatively small and highly polluted by trace metals, the species diversity of both carabids and ants in both study sites and both seasons is relatively high. However, the communities are established by common and widespread species in Poland and are highly dominated. The composition of species of carabid beetles and ants differed between the investigated sites. We suggest that these results reflect the reclamation practices that created variable microhabitats. This variability shapes the differences in the compositions of species, most likely due to the presence of more humid niches in Trzebionka, the comprehensively reclaimed tailing pond. The difference between the study sites was shown to be more important in shaping the species diversity of both carabids and ants than northern, southern, or eastern exposure. 


\section{Acknowledgements}

This study was financed by the Ministry of Science and Education (MNiSW), DS 3247/ZZŚ. We thank Tomasz Skalski for his help in the identification of carabids. Author contributions: MO designed the study and performed the experiment, IG participated in the identification of ants, and all authors contributed to the writing of the manuscript.

\section{References}

1. KICIŃSKA A., GRUSZECKA-KOSOWSKA A. Longterm changes of metal contents in two metallophyte species (Olkusz area of $\mathrm{Zn}-\mathrm{Pb}$ ores, Poland). Environ. Monit. Assess., 188, 339, 2016.

2. KARCZEWSKA A. Soil protection and reclamation of degradated areas Wydawnictwo Uniwersytetu Przyrodniczego we Wrocławiu, Wrocław, Poland, 2012 [In Polish].

3. TORDOFF G.M., BAKER A.J.M., WILLIS A.J. Current approaches to the revegetation and reclamation of metalliferous mine wastes. Chemosphere, 41, 219, 2000.

4. ROSA M.A., EGIDO J.A., MÁRQUEZ M.C. Enhanced electrochemical removal of arsenic and heavy metals from mine tailings. J. Taiwan Inst. Chem. E., 78, 409, 2017.

5. KARLFELDT FEDJE K., YILLIN L., STRÖMVALL A.M. Remediation of metal polluted hotspot areas through enhanced soil washing-Evaluation of leaching methods. J. Environ. Manage., 128, 489, 2013.

6. JEELANI N., YANG W., XU L., QIAO Y., AN S., LENG $\mathrm{X}$. Phytoremediation potential of Acorus calamus in soils co-contaminated with cadmium and polycyclic aromatic hydrocarbons. Sci. Rep.-Uk., 7, 8028, 2017.

7. KOMÁREK M., VANĚK A., ETTLER V. Chemical stabilization of metals and arsenic in contaminated soils using oxides-A review. Environ. Pollut., 172, 9, 2013.

8. GU H.H., ZHOU Z., GAO Y.Q., YUAN X.T., AI Y.J., ZHANG J.Y., ZUO W.Z., TAYLOR A.A., NAN S.Q., LI F.P. The influences of arbuscular mycorrhizal fungus on phytostabilization of lead/zinc tailings using four plant species. International Journal of Phytoremediation, 19 (8), 739, 2017.

9. CARSON W.P., ROOT R.B. Top-down effects of insect herbivores during early succession: influence on biomass and plant dominance. Oecologia, 121, 260, 1999.

10. HUNTER M.D., ADL S., PRINGLE C.M., COLEMAN D.C. Relative effects of macro invertebrates and habitat on the chemistry of litter during decomposition. Pedobiologia, 47, 101, 2003.

11. GOLLAN J.R., DE BRUYN L.L., REID N., SMITH D., WILKIE L. Can ants be used as ecological indicators of restoration progress in dynamic environments? A case study in a revegetated riparian zone. Ecological Indicators, 11, 1517, 2011.

12. EHRLE A., ANDERSEN A.N., LEVICK S.R., SCHUMACHER J., TRUMBORE S.E., MICHALZIK B. Yellow-meadow ant (Lasius flavus) mound development determines soil properties and growth responses of different plant functional types. Eur. J. Soil Biol., 81, 83, 2017.

13. JÍLKOVÁ V., PECH P., MIHALJEVIČ M., FROUZ J. Effects of the ants Formica sanguinea, Lasius niger, and
Tetramorium cf. caespitum on soil properties in an orewashery sedimentation basin. J. Soils Sediments, 17, 2127, 2017.

14. WANG C., WANG G., WU P., RAFIQUE R., ZI H., LI X., LUO Y. Effects of ant mounds on the plant and soil microbial community in an alpine meadow of QinghaiTibet plateau. Land Degrad. Develop., 28, 1538, 2017.

15. KLOJZY-KARCZMARCZYK B., MAZUREK J., CHOBOT C., MAKOUDI S., ŻÓŁTEK J., KUREK T. Technical documentation of the termination and reclamation of Z.G. "Trzebionka" S.A. tailing pond. Instytut Gospodarki Surowcami Mineralnymi i Energią PAN, Kraków, Poland, 2009 [In Polish].

16. TRAFAS M., ECKES T. Soil-making aspects in the evaluation of artificial formations; focus on the wastes formed after the flotation of zinc and lead ores. Geomatics and Environmental Engineering, 1, 97, 2007 [In Polish].

17. BAUEREK A., BEBEK M., SRACEK O., SMIEJA-KROL B. Chemical composition of surface runoff from flotation wastes of $\mathrm{Zn}-\mathrm{Pb}$ ore formation of the Mississippi Valleytype, Olkusz, Southern Poland. J. Geochem. Explor., 132, 54, 2013.

18. KUCZYŃSKA I.. Technical report on the influence of the elevation of ZGH "Bolesław” S.A., Kraków, Poland, 2009 [In Polish].

19. HŮRKA K. Carabidae of Czech and Slovak Republics; Kabourek, Zlín, Czech Republic, 1996.

20. CZECHOWSKI W., RADCHENKO A., CZECHOWSKA W., VEPSÄLÄINEN K. The ants of Poland with reference to the myrmecofauna of Europe; Museum and Institute of Zoology, Polish Academy of Sciences, Natura optima dux Foundation, Warszawa, Poland, 2012.

21. ALEKSANDROWICZ O.R. Carabids (Carabidae), in: The Fauna of Poland - characteristics and the list of species. T.1; Bogdanowicz W., Chudzicka E., Filipiuk I., Skibińska E. (Eds.), MiIZ PAN, Warszawa, Poland, 28, 2004 [In Polish].

22. SCHWERK A., SZYSZKO J. Succesion of carabid fauna (Coleoptera: Carabidae) on post-industrial areas near Bełchatów (Central Poland). Wiadomości Entomologiczne, 25, 71, 2006.

23. SCHWERK A. Changes in carabid beetle fauna (Coleoptera: Carabidae) along successional gradients in post-industrial areas in Central Poland. Eur. J. Entomol., 111 (5) 677, 2014.

24. BELSKAYA E.A., ZOLOTAREV M.P. Changes in the size structure of carabid communities in forest ecosystems under technogenic transformation. Russ. J. Ecol., 48 (2), 152-, 2017.

25. OLIVER T., ROY D.B., HILL J.K., BRERETON T., THOMAS C.D. Heterogeneous landscapes promote population stability. Ecol. Lett., 13, 473, 2010.

26. NEUMANN J.L., GRIFFITHS G.H., HOODLESS A., HOLLOWAY G.J. The compositional and configurational heterogeneity of matrix habitats shape woodland carabid communities in wooded-agricultural landscapes. Landscape Ecol., 31, 301, 2016.

27. MALLINGER R.E., GIBBS J.,GRATTON C. Diverse landscapes have a higher abundance and species richness of spring wild bees by providing complementary floral resources over bees' foraging periods. Landscape Ecol., 31, $1523,2016$.

28. PAPANIKOLAOU A.D., KÜHN I., FRENZEL M., SCHWEIGER O. Landscape heterogeneity enhances stability of wild bee abundance under highly varying temperature, but not under highly varying precipitation. Landscape Ecol., 32, 581-593, 2017. 
29. BAR-MASSADA A., WOOD E.M. The richnessheterogeneity relationship differs between heterogeneity measures within and among habitats. Ecography, 37, 528, 2014.

30. GAZOL A., TAMME R., PRICE J.N., HIIESALU I., LAANISTO L., PÄRTEL M. A negative heterogeneitydiversity relationship found in experimental grassland communities. Oecologia, 173, 545, 2013.

31. YANG Z., LIU X., ZHOU M., AI D., WANG G., WANG Y., CHU C., LUNDHOLM J.T. The effect of environmental heterogeneity on species richness depends on community position along the environmental gradient. Sci. Rep.-Uk., 5, 15723, 2015.

32. BUTTERFIELD J. Carabid community succession during the forestry cycle in conifer plantations. Ecography, 20, 614, 1997.
33. MAGURA T., TOTHMERESZ B. Testing edge effect on carabid assemblages in an oak-hornbeam forest. Acta Zool. Hung., 43, 303, 1997.

34. MAGURA T., TOTHMERESZ B., MONAR T. Spatial distribution of carabids along grass-forest transects, Acta Zool. Hung., 46, 1, 2000.

35. TRAFAS M. Changes in the properties of post-flotation wastes due to vegetation introduced during process of reclamation. Appl. Geochem., 11, 181, 1996.

36. SEIFERT B. Die Ameisen Mittel- und Nordeuropas, Lutra Verlags und Vertriebsgesellchaft, Görlitz, Germany, 2007.

37. HOLEC M., FROUZ J. Ant (Hymenoptera: Formicidae) communities in reclaimed and unreclaimed brown coal mining spoil dumps in the Czech Republic. Pedobiologia, 49, 345, 2005. 